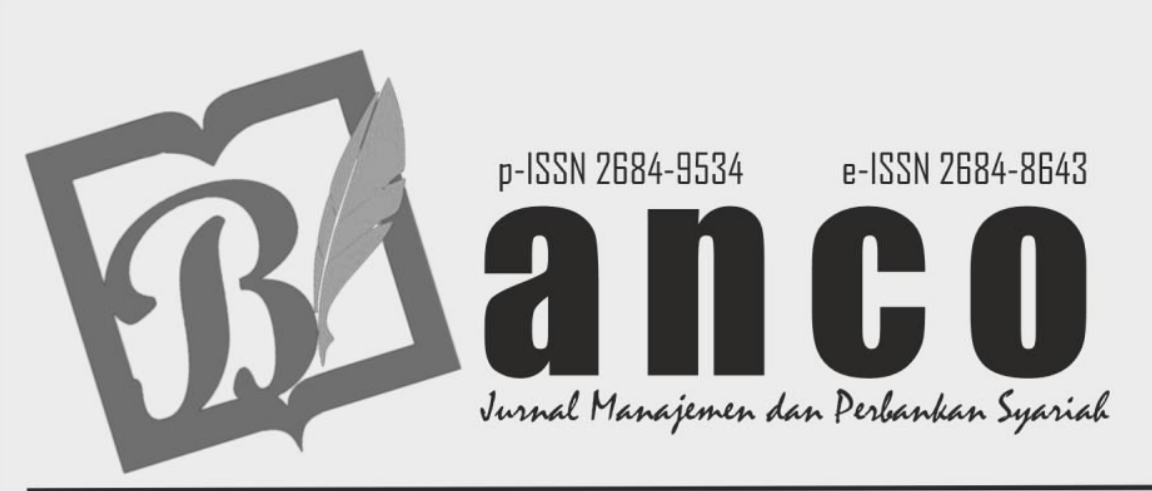

https://ejurnal.iainpare.ac.id/index.php/banco/index

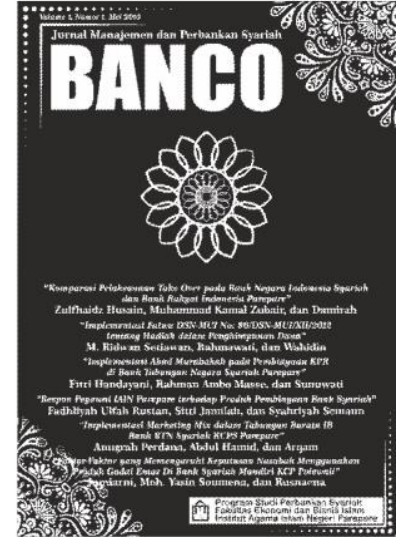

\title{
IMPLEMENTASI HYBRID CONTRACT PADA PEMBIAYAAN MURABAHAH BIL WAKALAH DI BNI SYARIAH CABANG MAKASSAR
}

\author{
Nurhikma \\ IAIN Parepare \\ nurhikma@institusi.ac.id
}

\author{
Rahman Ambo Masse \\ IAIN Parapare \\ rahmanambo@institusi.ac.id
}

\section{Damira}

IAIN Parepare

damira@institusi.ac.id

\section{Abstract}

Hybrid contract that is collecting two or more contracts in one financing. Murabaha financing product is an example of a financing product that is often compiled with a wakalah contract that aims to make customers free to choose the items needed because the bank is unable to provide all the items customers need. This study discusses the implementation of hybrid contracts in murabaha financing wakalah with a focus of research to determine the provisions of hybrid contracts in murabaha financing wakalah and implementation of the provisions of hybrid contracts murabaha bil wakalah BNI Syariah KC Makassar.

This study uses a qualitative method. Primary data in this study were obtained through direct observation and interviews. Whereas secondary data was obtained from literature such as browsers, Makassar Syariah KC Makassar Microfinance financing manuals and examples of murabahah contracts when the BNI Syariah KC Makassar was held.

The results of this study indicate that there are terms and conditions for murabaha financing wakalah contained in 22 articles which emphasize starting from the financing provisions to settling disputes in murabaha financing wakalah. The implementation of murabaha bil wakalah at BNI Syariah KC Makassar is also not fully in accordance with the provisions of Fatwa DSN-MUI No. 04 of 2000 concerning murabaha because the bank

Author correspondence email: nurhikma@institusi.ac.id

Available online at: https:// doi.org/10.35905/banco.v2i1.1345 


\title{
Nurhikma, Rahman Ambo Masse, Damira
}

did not explain the purchase price of the murabahah object to the customer so that it violated the provisions of Fatwa DSN-MUI No. 04 of 20006 about murabaha.

Keywords: Implementation, Hybrid Contract, Murabahah and Wakalah

\begin{abstract}
Abstrak
Hybrid contract yaitu menghimpun dua akad atau lebih dalam satu pembiayaan. Produk pembiayaan murabahah merupakan salah satu contoh produk pembiayaan yang seringkali dihimpun dengan akad wakalah yang bertujuan agar nasabah dapat dengan leluasa memilih barang yang dibutuhkan karena bank tidak mampu menyediakan semua barang keperluan nasabah. Penelitian ini membahas tentang Implementasi bybrid contract dalam pembiayaan murabahah bil wakalah dengan fokus penelitian untuk mengetahui ketentuan bybrid contract dalam pembiayaan murabahah bil wakalah dan implementasi ketentuan bybrid contract murabahah bil wakalah BNI Syariah KC Makassar.

Penelitian ini menggunakan metode kualitatif. Data primer dalam penelitian ini didapatkan melalui observasi dan wawancara langsung. Sedangkan data sekunder diperoleh dari literature seperti browser, bukubuku pedoman pembiayaan Mikro BNI Syariah KC Makassar dan contoh salinan akad murabahah bil wakalah BNI Syariah KC Makassar.

Hasil penelitian ini menunjukkan bahwa terdapat ketentuan dan syarat-syarat pembiayaan murabahah bil wakalah yang tertuan dalam 22 pasal yang menegaskan mulai dari ketentuan pembiayaan hingga penyelesaian perselisihan dalam pembiayaan murabahah bil wakalah. Pengimplementasian murabahah bil wakalah pada BNI Syariah KC Makassar juga belum sepenuhnya sesuai dengan ketentuan Fatwa DSN-MUI No. 04 tahun 2000 tentang murabahah karena bank tidak menjelaskan harga beli bank terhadap objek murabahah tersebut kepada nasabah sehingga hal tersebut melanggar ketentuan Fatwa DSN-MUI No. 04 tahun 2000 bulir 6 tentang murabahah.
\end{abstract}

Kata Kunci: Implementasi, Hybrid Contract, Murabahah dan Wakalah

\section{A. Pendahuluan}

Sistem Lembaga Keuangan, atau yang lebih khusus lagi disebut sebagai aturan yang menyangkut aspek keuangan dalam sistem mekanisme keuangan suatu Negara, telah menjadi instrumen penting dalam memperlancar jalannya pembangunan suatu bangsa. Indonesia yang mayoritas penduduknya beragama Islam tentu saja menuntut adanya sistem baku yang mengatur dalam kegiatan kehidupannya. Termasuk diantaranya kegiatan keuangan yang dijalankan oleh setiap umat. Hal ini berarti sistem baku termasuk dalam bidang ekonomi. Namun, didalam perjalanan hidup umat manusia kini telah berada dalam sistem perekonomian yang bersifat sekuler.(Fahmi, 2016)

Khusus di bidang perbankan, sejarah telah mencatat, sejak berdirinya De Javache Bank pada tahun 1872, telah menanamkan nilai-nilai sistem perbankan yang sampai sekarang telah mentradisi di kalangan masyarakat Indonesia, tanpa kecuali umat islam. (Jamin Ginting, 2017)

Suatu kemajuan yang cukup menggembirakan, menjelang abad XX terjadi kebangkitan umat islam dalam segala aspek. Dalam sistem, keuangan, berkembang pemikiran-pemikiran yang mengarah pada reorientasi sistem keuangan, yaitu yaitu dengan menghapuskan instrumen utamanya yaitu bunga. Usaha tersebut dilakukan dengan tujuan mencapai kesesuaian dalam melaksanakan prinsip-prinsip ajaran Islam yang mengandung dasardasar keadilan, kejujuran dan kebajikan.(Rahman, 2019)

Keberadaan perbankan Islam di tanah air telah mendapatkan pijakan kokoh setelah lahirnya Undangundang Perbankan Nomor 7 Tahun 1992 yang direvisi melalui Undang-Undang Nomor 10 tahun 1998, yang dengan tegas mengakui keberadaan dan berfungsinya Bank Bagi Hasil atau Bank Islam. (Segarawasesa, 2018). 
Dengan demikian, bank ini adalah yang beroperasi dengan prinsip bagi hasil. Bagi Hasil adalah prinsip muamalah berdasarkan syari'ah dalam melakukan kegiatan usaha bank. (Amir Machmud, 2010)

Rusby, 2017 menjelaskan secara teoritis, keunggulan perbankan syariah terletak pada sistem yang berdasarkan atas prinsip bagi hasil (profit and lost sharing) dan berbagi resiko (risk sharing) sistem ini diyakini para ulama sebagai jalan keluar untuk menghindari penerimaan dan pembayaran (bunga). Bank syariah dengan sistem bagi hasil dirancang untuk terbinanya kebersamaan dan menanggung resiko usaha dan berbagi hasil usaha antara pemilik dana (shahibul mal) yang menyimpan uangnya di lembaga, lembaga selaku pengelola dana (mudharib), dan masyarakat yang membutuhkan dana yang bisa berstatus peminjam dana atau pengelola usaha. Pengelolaan dana tersebut berdasarkan akad-akad yang disesuaikan dengan kaidah-kaidah muamalat. Dari segi ada atau tidaknya kompensasi, fikih muamalat membagi akad menjadi dua bagian, yaitu akad tabarru' dan akad tijarah.((2001), 2012)

Akad tabarru', yaitu segala macam perjanjian yang menyangkut non-profit transaction (transaksi nirlaba). Transaksi ini pada hakikatnya bukan transaksi bisnis untuk mencari keuntungan komersial. Akad tabarru' dilakukan dengan tujuan tolong-menolong dalam rangka berbuat kebaikan. Namun demikian, pihak yang berbuat kebaikan tersebut boleh meminta kepada counter part-nya untuk sekedar menutup biaya (cover the cost) yang dikeluarkannya untuk dapat melakukan akad tabarru' tersebut. Akan tetapi, ia tidak boleh sedikitpun mengambil laba dari akad tabarru' itu. Perbankan syariah akan dapat berkembang dengan baik apabila selalu berorientasi pada demand masyarakat (Rimadhani \& Erza, 2017). Dengan bermodalkan UU dan nilainilai moral, perbankan syariah harus mampu membuktikan bahwa keberadaannya mampu melayani kebutuhan masyarakat. Memang perbankan syariah beroperasi dengan sistem dan produk-produk yang berbeda dengan produk-produk perbankan konvensional. Namun, perbankan Indonesia menyiapkan perangkat ketentuan yang memungkinkan perbankan syariah dapat beroperasi secara optimal (Kholid, 2018).

Sejak bunga sebagai instrumen profit pada lembaga keuangan disepakati sebagai riba yang diharamkan menurut syariah, akad muamalah menempati tempat tersebut sebagai mekanisme dan instrumen pengganti dalam memperoleh profit pada lembaga keuangan syariah. Proses migrasi akad muamalah yang semula personal (individu) menjadi institusi (lembaga) karena diadopsi dan diadaptasi oleh lembaga keuangan menimbulkan kerumitan tersendiri yang dihadapi oleh praktisi lembaga keuangan(Amiruddin, 2018).

Kerumitan tersebut semakin terasa di era tranksaksi keuangan modern yang semakin kompleks, karena dibutuhkan desain kontrak (akad) dalam bentuk yang tidak hanya tunggal, tetapi mengkombinasikan beberapa akad, yang kemudian dikenal dengan istilah hybrid contract atau al- uqud al-murakkabah atau multiakad (Aprianti, 2014). Bentuk akad tunggal sudah tidak mampu merespon transaksi keuangan kontemporer yang selalu bergerak dan terpengaruh oleh industri nasional, regional maupun internasional. Istilah Hybrid contract pada bank syariah memang tidak asing lagi, hal ini dikarenakan dalam produk pembiayaan mikro perbankan syariah banyak yang menggunakan dua akad atau lebih dalam satu tranksaksi salah satunya pembiayaan mikro murabahah bil wakalah yang ada di bank BNI Syariah terkhusus di bank BNI Syariah KC Makassar. Menurut teori pengimplementasian murabahah bil wakalah pada bank syariah yaitu barang secara prinsip harus menjadi milik bank terlebih dahulu sehingga akad pertama yang harus digunakan adalah akad wakalah, setelah akad wakalah berakhir baru kemudian menggunakan akad murabahah.(Kariyono, 2019)

Berdasarkan pengamatan awal selama melakukan Program Pengalaman Lapangan di BNI Syariah memang disana terdapat pembiayaan murabahah bil wakalah yang diterapkan dan itu juga merupakan salah satu produk unggulan yang banyak diminati oleh nasabah akan tetapi, diperkirakan terdapat kesenjangan terhadap pengimplementasian hybrid contract pada pembiayaan murabahah bil wakalah yang diterapkan disana, dimana akad murabahah dilakukan sebelum akad wakalah berakhir. Dari permasalahan tersebut peneliti tertarik untuk meneliti lebih jauh terkait masalah tersebut. 


\section{B. Diskusi dan Pembahasan}

\section{Gambaran Umum BNI Syariah Cabang Makassar}

PT. Bank BNI Syariah KCU Makassar merupakan lembaga keuangan syariah yang lokasinya sangat strategis dan sangat mudah di jangkau oleh masyarakat yang beralamat di Jl. DR. Ratulangi, Parang, Kec. Mamajang, Kota Makassar, Sulawesi Selatan. Yang semula berlokasi di jalan AP. Pettarani Ruko Sardony mulai tanggal 18 Mei 2017 berpindah ke Jalan DR. Sam Ratulangi, yang merupakan salah satu dari 8 aset gedung kantor Cabang BNI Syariah. Makassar sebagai ibukota provinsi Sulawesi selatan yang merupakan kota metropolitan terbesar di Indonesia timur, serta merupakan salah satu kota di Indonesia yang memiliki laju pertumbuhan ekonomi yang paling tinggi. Hal ini yang mendorong BNI Syariah untuk membuka layanan di kota Makassar sejak tahun 2001.

Dengan adanya lokasi baru yang lebih strategis, lebih besar dan lebih nyaman akan memberikan tambahan semangat baru bagi segenap karyawan BNI Syariah untuk memberikan layanan yang lebih baik. Berkat dukungan seluruh stakeholders, hingga Maret 2017 BNI Syariah tumbuh kea rah positif. Hal tersebut ditandai dengan pertumbuhan aset sebesar 21.01\% menjadi Rp 29,86\% dan pertumbuhan Dana Pihak Ketiga (DPK) sebesar 23,38\%. Pertumbuhan tersebut diikuti dengan pertumbuhan kinerja positif KC BNI Syariah Makassar Per Maret 2017 tercatat laba yang didapat sebesar Rp 13,8 Miliar dengan total penghimpunan DPK sebesar Rp 596 Miliar dan Pembiayaan sebesar Rp 561 Miliar. Hal tersebut menunjukan bahwa kehadiran BNI Syariah disambut baik oleh masyarakat.

2. Ketentuan Hybrid Contract pada Pembiayaan Murabahah bil Wakalah di BNI Syariah Cabang Makassar

Produk pembiayaan merupakan salah satu produk dari bank BNI Syariah dan bank-bank lainnya, yang merupakan pemberian fasilitas penyaluran dan penyediaan dana dari pihak-pihak yang surplus unit untuk membantu memenuhi kebutuhan pihak-pihak yang merupakan defisit unit salah satunya di Bank BNI Syariah Cabang Makassar

Hybrid contract itu sendiri merupakan kesepakatan dua pihak untuk melaksanakan suatu muamalah yang meliputi dua akad atau lebih. (Hidayati et al., 2021). Istilah Hybrid Contract atau penggunaan dua akad atau lebih dalam suatu pembiayaan pada instansi lembaga keuangan memang banyak digunakan, hal tersebut merupakan cara bank atau lembaga keuangan lainnya untuk mempermudah jalannya suatu pembiayaan yang memerlukan akad pelengkap meskipun tidak semua pembiayaan memerlukan akad pelengkap dan tidak semua akad boleh di gabungkan. (Kurniawan, 2021)

Ibrahim \& Salam, (2021) menjelaskan bahwa menghimpun dua akad atau lebih dalam satu pembiayaan memang dibolehkan menurut DSN MUI selaku otoritas ulama di Indonesia meskipun ada beberapa hadits yang melarang transaksi tersebut. Akan tetapi sebenarnya menghimpun dua akad atau lebih di haramkan apabila dua akad tersebut menimbulkan riba atau menyerupai riba seperti menggabungkan qardh dengan akad yang lain, seperti qardh dengan jual beli. (Masnah \& Hendrawati, 2020). Demikian pula menggabungkan jual beli cicilan dengan jual beli cash, meskipun penggabungan akad tersebut dilarang akan tetapi hal tersebut masih banyak di terapkan dalam beberapa kegiatan usaha. Sedangkan dalam praktik yang ada di bank BNI Syariah Cabang Makassar implementasi bybrid contract yang diterapkan hanya murabahah bil wakalah, hal tersebut sesuai dengan apa nyang dijelaskan"Salam M Bustan" bahwa:

"Disini kita hanya pake multiakad murabahah bil wakalah saja, kalau untuk pembiayaan lain belum ada yang pake dua akad atau lebih, yang murabahah bil wakalah saja yang diterapkan disini baru kita pakai kalau bank benar-benar tidak mampu atau tidak bisa turun tangan langsung untuk beli objek yang na mau nasabah, menurut pemahaman dari saya pribadi sebenarnya ini multiakad tidak sembarang 
diterapkan juga dilembaga keuangan syariah, ditakutkan kalau diterapkan juga terjadi penyimpangan didalamnya yang melanggar prinsip syariah"(Rimadhani \& Erza, 2017)

Berdasarkan hasil wawancara diatas diperoleh data bahwa penggunaan bybrid contract dalam pembiayaan yang diterapkan di BNI Syariah Cabang Makassar hanyalah murabahah bil wakalah meskipun penerapan akad wakalah dalam pembiayaan murabahah tidak selalu digunakan. Pihak bank lebih sering menggunakan murabahah murni dalam produk pembiayaannya. penerapan akad wakalah hanya dilakukan apabila bank benar-benar tidak bisa turun langsung membeli objek murabahah yang di perlukan nasabah baru kemudian pihak bank memberikan akad wakalah.

Dalam suatu pembiayaan penggunaan bybrid contract atau multiakad memang tidak serta merta harus selalu digunakan dalam suatu pembiayaan, penggunaan bybrid contract dalam pembiayaan hanya sebagai pelengkap saja apabila pihak lembaga keuangan syariah memerlukan akad lain untuk membantu memudahkan jalannya suatu pembiayaan.

Penggunaan bybrid contract juga tidak serta merta langsung diterapkan dalam produk pembiayaan karena dalam hal ini memang ada akad yang sangat dilarang untuk dihimpun dengan akad lain dikarenakan apabila kedua akad tersebut disertakan maka, akan menimbulkan penyimpangan yang melanggar prinsip syariah yakni seperti akad jual beli dengan Qard (memberi pinjaman), larangan ini bertujuan untuk menghindari terjerumusnya seseorang kepada riba yang diharamkan, contohnya seperti seseorang ingin membeli sebuah pulpen akan tetapi tidak memiliki uang dan salah seorang lainnya ingin menjual pulpennya dengan harga 800 , agar pulpennya bisa laku dengan harga yang semula 800 menjadi harga 1.000, si penjual tersebut meminjamkan uang kepada orang yang ingin membeli pulpen tersebut sebanyak 1.000 untuk kemudian uang tersebut dipakai untuk membeli pulpen yang tadinya seharga 800 menjadi 1,000. Artinya pihak yang bertindak sebagai penjual dan pemberi pinjaman tersebut memperoleh keuntungan lebih sebanyak 200 dari hasil meminjamkan uang tersebut untuk membeli pulpen darinya. hal tersebut yang menjadi salah satu contoh mengapa tidak semua akad dapat digabungkan. (SN Rokhmana, 2012)

Hybrid contract dalam pembiayaan murabahah bil wakalah artinya menghimpun dua akad yang berbeda dalam satu pembiayaan yakni akad murabahah dan akad wakalah yang memiliki ketentuan serta syarat-syarat dalam pengimplementasiannya pada bank BNI Syariah Cabang Makassar yang telah diatur dalam Surat Keputusan Pembiayaan (SKP) yang menjadi bagian tak terpisahkan dalam akad Murabahah.

Berdasarkan hal tersebut apabila pembiayaan murabahah yang digunakan disertakan dengan akad wakalah maka sesuai dengan kesepakatan para pihak dan sesuai dengan ketentuan yang berlaku bahwa akad pembiayaan murabahah harus di dahului terlebih dahulu dengan akad wakalah. hal tersebut sesuai dengan penjelasan “A. Kardita Savitri” Bahwa:

"Disini kalau pembiayaan yang di ambil pake akad murabahah bil wakalah itu memang harus kita dahulukan akad wakalah dulu karna itu memang sudah menjadi ketentuan yang tidak boleh kita ubah karna kan itu akad wakalah adalah akad pemberian kuasa dimana bank berikan kuasa kepada nasabah untuk membeli barang yang dia mau karna bank tidak punya stock barang yang dibutuhkan nasabah"

Hal senada juga dijelaskan oleh "Andi Wina" bahwa

"Sebenarnya, secara teori jika membahas mengenai akad yang harus didahulukan terlebih dahulu jika mengambil pembiayaan yang menggunakan akad murabahah bil wakalah tentunya kita harus mendahulukan akad wakalah karena jika barang secara prinsip belum menjadi milik bank sedangkan bank dengan nasabah telah melakukan penandatangan akad murabahah berarti itu sudah terjadi penyimpangan dong, artinya bank sudah menjual barang yang belum ada dan itu menunjukkan sifat gharar yang dilarang dalam islam. Kalau kita disini menjalankan pembiayaan tersebut sesuai dengan 


\section{Nurhikma, Rahman Ambo Masse, Damira}

aturannya akan tetapi di bank-bank syariah lainnya dan tidak menutup kemungkinan juga Bank BNI Syariah cabang lain menjalankan pembiayaan tersebut tidak sesuai dengan ketentuannya, itu sebenarnya tergantung dari oknum-oknum yang bertanggung jawab didalamnya karena biasanya mereka ingin simplenya saja tanpa memikirkan apakah itu melanggar ketentuan atau tidak, kebanyakan dari mereka tidak mau repot kalau harus bolak balik tandatangani akad, jadi mereka langsung saja kasih akad murabahah sama wakalahnya untu tandatangani secara bersamaan meskipun barang secara pinsip belum jadi miliknya bank"

3. Implementasi Ketentuan Hybrid Contract Pada Pembiayaan Murabahah bil Wakalah di BNI Syariah Cabang Makassar

Terdapat beberapa macam Produk Pembiayaan yang ada di Bank BNI Syariah Cabang Makassar yang diantaranya menggunakan akad murabahah yang merupakan akad unggulan yang diterapkan di semua bidang perbankan syariah dalam produk pembiayaannya. akad murabahah yang dalam penerapannya memang telah diatur dalam Fatwa Dewan Syariah Nasional No: 04/DSN/MUI/IV/2000 Tentang Murabahah. jadi, secara prinsip dan aturan penerapan murabahah sesuai dengan prinsip syariah. Produk pembiayaan murabahah memang salah satu produk yang paling sering digunakan di Bank Syariah khususnya di BNI Syariah Cabang Makassar. Proses pembiayaan yang menggunakan akad murabahah tersebut memiliki beberapa tahap sebagaimana yang dijelaskan oleh "Salam M. Bustan" bahwa:

"Dalam tranksaksi Murabahah Murni awalnya itu nasabah melihat objek atau barang yang akan dibelinya terlebih dahulu kepada Supplier atau Develover baru kemudian, ini nasabah na sampaikan objek yang akan dia beli pada pihak bank, baru kemudian pihak bank pergi melihat objek yang disampaikan nasabah dari Supplier/Develover untuk diteliti barangnya dulu. setelah itu Bank kemudian meneliti berkas Nasabah apakah benar dia layak diberikan pembiayaan tersebut. kalau layak, Bank baru pergi beli barang yang di minta nasabah dari Supplier/Develover. Setelah barang menjadi miliknya Bank, baru Bank menjual kepada Nasabah dengan harga jual = harga beli + Margin yang disepakati bersama."

Sejalan dengan hal tersebut dalam penerapan dan perkembangannya, akad murabahah ini mengalami modifikasi. Yakni, setiap melakukan pembiayaan dengan akad murabahah terkadang disertai dengan akad wakalah meskipun hal tersebut tidak berlaku setiap melakukan pembiayaan murabahah. jika pihak bank masih bisa untuk turun langsung dalam hal membeli objek murabahah yang diminta oleh nasabah, pihak bank tidak perlu memberikan akad wakalah hal tersebut sesuai dengan penjelasan "Salam M. Bustan" yang mengatakan bahwa:

"Sebenarnya disini, pembiayaan murabahah bil wakalah tidak selalu digunakan, artinya kadang kita juga lebih sering gunakan murabahah murninya saja. Selama kita masih bisa turun langsung untuk belikan nasabah barang yang dia mau contohnya itu kayak nasabah mau beli mobil. Itu biasanya kita pake murabahah murni ji karna masih bisaki handle ki itu, ituji biasa ki pake Murabahah bil Wakalah kalau kita tidak bisa turun langsung kayak produk BNI Griya IB Hasanah untuk merenovasi rumah atau ruko, kita sebagai pihak bank tidak mungkin pergi belikan pasir, semen kerikil dan lain-lain. Jadi biasanya kalau pembiayaan begitu kita baru pake Murabahah bil Wakalah."

Berdasarkan hasil wawancara diatas peneliti juga melakukan wawancara dengan salahsatu nasabah Bank BNI Syariah Cabang Makassar yang mengambil pembiayaan menggunakan akad murabahah "Zurya Achmady M" yang mengatakan bahwa:

"Pembiayaan yang saya ajukan itu untuk membeli rumah BTN yang rencananya nanti mau saya kontrakkan lagi tapi saya tanda tangani akad murabahah saja, tidak ada akad wakalahnya karna bank ji yang langsung beli bukan ji saya, setelah na beli bank baru saya yang beli lagi di bank secara angsuran". 
Berbeda halnya dengan pembiayaan murabahah murni tanpa menyertakan akad wakalah didalamnya. Pelaksanaan pembiayaan murabahah dengan penyertaan akad wakalah didalamnya memiliki tahapan yang berbeda pula dengan pembiayaan yang hanya menggunakan akad murabahah murni dengan kata lain alur yang dilakukan juga berbeda dengan adanya penyertaan akad wakalah tersebut., sebagaimana yang dijelaskan oleh "Muh Saleh" bahwa:

"Itu kalau kita sertakan akad wakalah dalam pembiayaan murabahah otomatis berubah juga skema alurnya, awalnya itu nasabah pergi na lihat objek yang dia mau atau dia ingin beli to, kemudian kalau objek barang yang dia mau sudah ada baru kemudian na sampaikan kepada bank, itu objek barang yang dia mau. Setalah bank melihat objek barang dan meneliti objek tersebut baru kemudian pihak bank meneliti berkas nasabah apakah nasabah tersebut layak untuk diberikan pembiayaan. kemudian apabila nasabah tersebut dinyatakan layak dan bank tidak mampu melaksanakan tugasnya barulah kemudian bank memberi akad wakalah kepada nasabah untuk membeli atas nama bank syariah dengan menggunakan akad murabahah bil wakalah kepada Supplier/Develover. Setelah objek murabahah dibeli oleh nasabah atas nama bank syariah, objek tersebut kembali diserahkan terlebih dahulu kepada Bank Syariah untuk diteliti kebenarannya.setelah barang menjadi milik Bank, barulah bank menjual kepada nasabah dengan harga jual = Harga Beli + Margin yang disepakati bersama."

Akad murabahah adalah akad yang digunakan pada produk pembiayaan mikro dan dalam pembiayaan mikro tersebut memiliki beberapa jenis berdasarkan tujuan nasabah yang mengajukan permohonan pembiayaan. Beberapa tujuan nasabah mengambil pembiayaan yaitu untuk modal kerja, Investasi dan konsumtif.(Kusuma, 2019)

Pengungkapan harga pokok dalam pembiayaan murabahah murni maupun murabahah bil wakalah pada bank BNI Syariah cabang mengalami sedikit perubahah yakni tidak dijelaskannya harga pokok didalamnya karena dianggap mengurangi kesyariahan pembiayaan tersebut sehingga masih banyak di kritisi mengenai hal tersebut. Seperti yang dijelaskan oleh "Salam M Bustan" bahwa :

"Kalau pengungkapan harga pokok dan margin kepada nasabah disini sudah mengalami perubahan. Awalnya disini harga pokok atau harga beli kita jelaskan juga pada saat akad kepada nasabah tapi sekarang harga pokok tidak lagi kita sebutkan pada saat akad karna itu bisa mengurangi kesyariahannya. Contohnya, dulu itu kita jelaskan anggaplah uang muka 20juta, harga beli bank 100juta, keuntungan bank 50juta dan harga jual bank sebanyak 150 juta. Nah distu jelas sekali harga pokoknya kan. Seharusnya kalau kita mengikuti aturan syariah harusnya harga pokok tidak disebutkan karna dalam istilah syariah pokok dan margin ini satu kesatuan, yang disebutkan itu hanya harga jual bank, keuntungan bank, uang muka dan sisa kewajiban bank."

Berdasarkan hasil wawancara diatas, dalam ketentuan pasal 2 tentang pembiayaan pada akad murabahah bil wakalah di bank BNI Syariah cabang makassar telah mengalami sedikit perubahan karena dalam pembiayaan dengan akad murabahah bil wakalah harga perolehan atau harga pokok sudah tidak lagi disebutkan pada saat akad karena harga pokok dengan margin menurut pandangan bank BNI Syariah KC Makassar merupakan satu kesatuan yang dianggap mengurangi kesyariahan dari akad murabahah apabila dijelaskan pula mengenai harga pokoknya sedangkan pada awalnya dalam ketentuan pasal 2 tentang pembiayaan murabahah bil wakalah harus disebutkan harga beli dan margin keuntungan bank hal tersebut juga sesuai dengan definisi pembiayaan murabahah yang tertuan dalam pasal 1 yakni akad murabahah adalah akad pembiayaan suatu barang dengan menegaskan harga belinya kepada nasabah dan nasabah membayar kepada bank dengan harga jual bank, yaitu harga beli ditambah keuntungan yang disepakati.

Apabila bank tidak menegaskan harga pokok dari objek murabahah tersebut hal itu juga melanggar ketentuan Fatwa Dewan Syariah Nasional No: 04/DSN/-MUI/IV/2000 tentang Murabahah bulir 6 yaitu "Bank kemudian menjual barang tersebut kepada nasabah (pemesan) dengan harga jual senilai 


\section{Nurhikma, Rahman Ambo Masse, Damira}

harga beli ditambah keuntungannya. Dalam kaitan ini bank harus memberitahu secara jujur harga pokok barang kepada nasabah berikut biaya yang diperlukan".

Dalam pembiayaan mikro pada Bank BNI Syariah Cabang Makassar yang menggunakan akad murabahah memiliki tujuan pembiayaan yang dipilih nasabah apabila ingin melakukan pembiayaan dengan menggunakan akad murabahah bil wakalah yakni untuk pembiayaan modal kerja, investasi dan konsumtif setinggi-tingginys $50 \%$ dari tujuan produktif nasabah tersebut sesuai dengan ketentuan pasal 3 tentang tujuan pembiayaan. pembiayaan mikro ini diperuntukan bagi wirausaha atau pengusaha dengan lama usaha minimal 2 tahun.

\section{a. Jenis-Jenis Pembiayaan Konsumtif BNI Syariah Cabang Makassar}

Pada Bank BNI Syariah terdapat beberapa macam produk pembiayaan konsumtif yang dilengkapi dengan keunggulan masing-masing yang dalam pembiayaan tersebut semuanya menggunakan akad murabahah :

1) BNI Griya IB Hasanah, yaitu fasilitas pembiayaan konsuntif untuk membeli, membangun, merenovasi rumah/ruko ataupun untuk membeli kavling siap bangun (KSB).

2) BNI Multiguna iB Hasanah, yaitu fasilitas pembiayaan konsumtif yang diberikan kepada anggota masyarakat untuk pembelian barang dan penggunaan jasa dengan agunan berupa rumah tinggal.

3) BNI Emas iB Hasanah, yaitu fasilitas pembiayaan konsumtif yang diberikan untuk membeli emas

Realisasi pembiayaan pada Bank BNI Syariah Cabang Makassar dilakukan apabila syarat serta ketentuan pembiayaan telah dipenuhi seperti verifikasi awal melalui Bi Cheking nasabah, Kelengkapan berkas nasabah kemudian dilakukan analisa terhadap data agunan nasabah hal tersebut yang didasarkan pada ketentuan pasal 5 terkait realisasi pembiayaan.

Berdasarkan hasil wawancara yang diperoleh peneliti di Bank BNI Syariah Cabang Makassar, diperoleh data tentang alur pembiayaan murabahah bil wakalah yang dibedakan menjadi tiga tujuan yaitu pembiayaan modal kerja, investasi dan konsumtif. Peneliti akan menjelaskan bagaimana alur pembiayaan konsumtif karena secara garis besar ketiga tujuan pembiayaan tersebut alurnya sama yakni menggunakan akad murabahah yang juga kadang menyertakan akad wakalah didalamnya. Seperti yang dijelaskan oleh "Asdar" bahwa :

"Sebenarnya semuanya sama ji karna sama-sama menggunakan akad murabahah yang biasa juga kadang sertakan dengan akad wakalah. Investasi, konsumtif dan modal kerja, semua harus ada DPnya semua, kalau aturannya minimal 20\%".

\section{b. Alur Pembiayaan Murabahah Konsumtif}

Nasabah datang ke bank untuk mengajukan permohonan pembiayaan dengan membawa persyaratan yang ditentukan. Sales assistant memverifikasi awal permohonan pembiayaan nasabah, baik melalui BI Cheking ataupun melalui data lapangan . Seperti yang dikatakan oleh "Fadliansyah" bahwa:

"BI Cheking adalah penentu untuk memberi pinjaman, kalau BI Chekingnya jelek mau diapa kasih lagi pinjaman, tahapan prosesnya itu banyak. Proses pengajuan pinjaman bukan bilang besar usahanya pasti banyak untungnya bisa layak diberikan pinjaman, tidak berpatokan dari situ. Yah kalau diperiksa ternyata jelek identitasnya itu nasabah nda bisa juga diberikan pinjaman tapi, kalau BI Chekingnya bagus usahanya juga bagus nah itu baru layak diberikan pinjaman, intinya kalau surat pengajuanmu sudah masuk di bagian marketing disitu mulaimi memang di periksa semua cuma disana pemeriksaanya masih kasar".

Pada saat nasabah ingin mengajukan pembiayaan sangat penting untuk dilakukan pengecekan terlebih dahulu BI Chekingnya. Karena BI Cheking merupakan penentu layak atau tidaknya nasabah 
tersebut diberikan pembiayaan meskipun usaha nasabah bagus akan tetapi pada saat diperiksa dan ternyata BI Chekingnya jelek maka nasabah tersebut tidak dapat diberikan pembiayaan karena untuk mendapatkan persetujuan pembiayaan dari bank, nasabah harus memiliki usaha yang bagus serta BI Cheking yang bagus.

Sales assistant menyerahkan data agunan nasabah kepada Consumer Financing Assistant (CPH) untuk kemudian dilakukan review dan dilakukan analisa kembali terhadap data agunan nasabah. Ketentuan agunan pada bank BNI Syariah Cabang Makassar merupakan sesuatu yang wajib adanya untuk semua jenis ataupun tujuan pembiayaan baik itu yang bergerak ataupun tidak bergerak, baik yang sudah ada maupun yang akan ada dikemudian hari. Itu akan menjadi jaminan pelunasan seluruh utang nasabah. Hal tersebut sesuai dengan penjelasan"Fadliansyah" bahwa:

"Kalau disini agunan itu wajib, apapun tujuan pembiayaannya semuanya wajib memberikan agunan mau itu pembiayaan konsumtif, modal kerja ataupun investasi, nilai agunannya juga kami perhitungkan, tidak mungkin dia ambil pembiayaan 500juta sedangkan nilai agunannya itu 100juta"

Pemberian agunan dalam pembiayaan murabahah juga telah sesuai dalam Fatwa Dewan Syariah Nasional No: 04/DSN/-MUI/IV/2000 ketentuan jaminan dalam murabahah point pertama "Jaminan dalam murabahah dibolehkan, agar nasabah serius dengan pesanannya”. (Harahap \& Saraswati, 2020). Bukti kepemilikan barang agunan tersebut juga harus diserahkan kepada pihak bank serta data agunan tersebut harus ditandatangani oleh pemegang hak dan bank serta harus diterima oleh bank sebelum direalisasikannya pembiayaan tersebut. hal itu telah diatur dalam pasal 10 tentang agunan dalam ketentuan akad murabahah dan semua rincian serta biaya-biaya pengikatan serta biaya premi asuransi jiwa, gangguan usaha dan asuransi kerugian atas barang-barang jaminan harus sudah dibayar lunas atau di cadangkan oleh nasabah dibawah penguasaan bank sebelum dilakukan realisasi hal tersebut juga telah diatur dalam pasal 11 tentang asuransi serta beban biaya-biaya yang diatur dalam pasal 12 dalam ketentuan akad murabahah.(Tripalupi, 2020)

Setelah dilakukan analisa terhadap data agunan nasabah oleh Consumer Financing Assistant (CPH) selanjutnya, data tersebut di berikan kepada pemutus yang memiliki tugas dan wewenang masingmasing. Seperti yang dikatakan "Fadliansyah" bahwa:

"Kalau pemutus disini tidak hanya satu orang saja tapi, ada dua orang yang pertama itu ada Bussines Manager (BNM) kemudian ada juga yang dibilang Branch Manager, kalau pembiayaan yang diajukan itu maksimal 500 Juta berarti yang tangani itu Cuma Bussines Manager tapi, kalau pembiayaan yang diajukan itu lebihmi dari 500 Juta yang tangani itu Branch Manager.”

Setelah melalui tahap tersebut, selanjutnya data agunan nasabah diberikan kepada bagian Financing Administrasi Head (FAH) untuk kemudian diberikan surat keputusan kepada nasabah bahwa pengajuan pembiayaan tersebut telah disetujui dan biaya-biaya yang timbul dalam proses itu akan di bebankan kepada nasabah yang selanjutnya akan dibuatkan akad Murabahah dan Wakalah.

Setelah semua proses penandatanganan akad murabahah dan wakalah selesai selanjutnya Collection Assistant yang yang menjalankan tugasnya dalam hal memantau angsuran nasabah sampai lunas. Pelunasan pembiayaan nasabah kepada bank wajib dilakukan secara angsuran sesuai dengan jadwal angsuran pembiayaan tersebut yang dilakukan mengunakan jasa layanan PUAN (Penjemputan Uang Angsuran Nasabah) atau nasabah yang langsung ke bank dalam hal melakukan setoran angsuran setiap hari kerja kemudian pihak bank yang bertugas malakukan layanan PUAN ataupun yang menerima setoran angsuran langsung dari nasabah akan dibukukan yang selanjutnya akan dilakukan pendebetan oleh bank, hal tersebut sesuai dengan penjelasan "Fadliansyah" bahwa: 


\section{Nurhikma, Rahman Ambo Masse, Damira}

"Kalau uang angsuran nasabah disini biasa dibayar langsung oleh nasabah di bank, ya kalau nasabah tidak datang membayar biasanya kita jemput. Disini ada yang namanya layanan PUAN (Penjemputan Uang Angsuran Nasabah) kalau untuk layanan itu kita lakukan secara bergilir".

Hal tersebut juga telah diatur dalam ketentuan pembiayaan murabahah bil wakalah pasal 6 tentang pembayaran angsuran pembiayaan.

Dari alur di atas dapat dideskripsikan bahwa ketika nasabah datang dan mengajukan pembiayaan konsumtif kepada Bank BNI Syariah, maka pihak bank akan menunjukan persyaratan apa saja yang harus dipenuhi sesuai dengan jenis pembiayaan yang diambil. Selain itu juga akan dilakukan uji kelayakan nasabah melalui BI Checking yang dilakukan oleh Sales assistant. Setelah nasabah sudah melengkapi persyaratan yang yang telah ditetapkan oleh pihak bank dan pengecekan BI Chekingnya bagus Maka selanjutnya, Consumer Financing Assistant (CPH) yang akan memeriksa dan mereview kembali berkas atau data agunan nasabah. Selanjutnya setelah melalui tahap tersebut dan dinyatakan layak, berkas tersebut selanjutnya diberikan kepada pemutus yaitu Bussines Manager (BNM) yang menangani pembiayaan maksimal Rp 500Juta dan apabila pembiayaan yang diminta lebih dari itu maka akan dialihkan oleh Branch Manager.

Selanjutnya, pada bagian Financing Administrasi Head (FAH) akan memberikan surat pemberitahuan kepada nasabah bahwa pembiayaan tersebut telah disetujui dan seluruh biaya-biaya seperti notaris dan lain sebagianya akan dibebankan kepada nasabah dan selanjutnya akan diberikan akad wakalah dan akad murabahah hingga proses pembelian objek tersebut selesai. Barulah kemudian Collection Assistant yang akan memantau angsuran nasabah tersebut sampai lunas.

Dalam pembiayaan murabahah bil wakalah pada Bank BNI Syariah Cabang Makassar apabila dikemudian hari nasabah dengan sengaja atau karena lalai dan tidak melakukan pemabayaran angsuran kepada bank, maka nasabah harus mengganti kerugian bank yakni sebesar 100\% dari jumlah kerugiaan rillnya yang wajib dibayar lunas oleh nasabah. Cara yang dilakukan pihak bank apabila terjadi hal seperti itu telah diatur dalam ketentuan pembiayaan dalam akad murabahah bil wakalah pasal 7. Pihak bank BNI Syariah KC Makassar akan mengirimkan surat peringatan terlebih dahulu kepada nasabah yang bersangkutan melalui kurir atau diantar sendiri oleh pihak bank sesuai pasal 16 tentang korespondensi. hal tersebut juga dijelasan oleh "Fadliansyah" bahwa:

"Kalau ada nasabah yang bermasalah, seperti tidak mau membayar angsuran pembiayaannya, biasanya kita kasih dulu surat teguran kalau sudah dikasih dan nasabah belum juga melakukan kewajibannya baru kemudian kita turun langsung biasanya itu kalau agunan pembiayaanya itu berupa bangunan atau lahan kosong biasnya kita berikan papan tanda atau stiker"

Dalam ketentuan pasal 14 tentang peristiwa cedera janji dalam rangka melakukan penyelamatan pembiayaan maka bank berwenang dalam hal memasang papan tanda, stiker terhadap agunan nasabah atau menggunakan pihak ketiga untuk melakukan penagihan pelunasan pembiayaan sesuai dengan ketentuan pasal 15. Hal tersebut sesuai dengan penjelasan "Muh Saleh"

"Kalau seumpama nasabahnya tidak mampu lagi bayar angsuran pembiayaannya, kan ada jaminannya. Kalau sudah dikasih surat teguran lantas belum na tunaikan kewajibannya dan tidak ada konfirmasinya, baru kita turun untuk lakukan sesuatu sesuai dengan perintah atasan, kalau jaminannya rumah biasanya rumahnya kita kasih papan tanda."

Sedangkan apabila terjadi wanprestasi atau cedera janji bank juga memiliki wewenang untuk mengakhiri jangka waktu pembiayaan jika nasabah tidak mampu membayar angsuran pembiayaannya dan nasabah wajib membayar lunas sekaligus utangnya dengan tenggang waktu yang diberikan pihak bank. Hal tersebut telah diatur dalam ketentuan murabahah bil wakalah pasal 13. Hal tersebut sesuai dengan penjelasan "Muh Saleh" Bahwa" 
"Kalau nasabah tidak bisa penuhi kewajibannya disini kita punya wewenang untuk membatalkan perjanjian atau akadnya. Biasanya itu nasabah tidak bisa bayar angsurannya padahal sudah jatuh tempo kecuali, kan sesuatu yang akan terjadi dimasa yang akan datang tidak bisa diperkirakan misalnya nasabah mendapat musibah kebakaran atau dirampok kita pihak bank biasanya bisa memberikan toleransi pembayaran tapi, harus ada surat keterangan bahwa benar nasabah ini mendapat masalah seperti yang dinyatakan dari kepolisian"

Apabila dalam masa pembiayaan terjadi keadaan memaksa (Force majeure) sesuai dengan hasil wawancara diatas seperti terjadi kebakaran ataupun bencana alam yang dilengkapi dengan bukti secukupnya dari pihak yang berwenang mengenai terjadinya keadaan memaksa tersebut sehingga nasabah tidak mampu memenuhi kewajibannya dalam hal membayar angsuran pembiayaannya. Maka pihak bank akan memberikan waktu hingga berakhirnya keadaan memaksa tersebut hal tersebut telah diatur dalam pasal 17.

Dalam penyelenggaraan rekening pembiayaan yang telah diatur dalam ketentuan pasal 8, pelaksanaan pembiayaan dengan akad murabahah bil wakalah nasabah juga diwajibkan untuk membuka rekening pembiayaan serta rekening tabungan tersendiri atas nama nasabah yang dilakukan di bank tempat pelaksanaan pembiayaan tersebut yang digunakan untuk keperluan administrasi hal tersebut juga sesuai dengan pasal 9 tentang kuasa bank atas rekening nasabah dan berkaitan denagn pasal 21 tentang tambahan. Hal tersebut sesuai dengan penjelasan "Asdar " bahwa:

"Nasabah harus punya rekening tabungan dan rekening pembiayaan, karna memang itu sudah menjadi aturannya, kan nanti saldo rekening tabungan akan di blokir sebanyak ssatu kali angsuran, rekening pembiayaan,biaya pengelolaan rekening dan lainnya setiap bulan sampai selesai pembiayaannya"

Jadi, bank miliki kuasa atas rekening nasabah untuk mendebet tabungan atau rekening pembiayaan nasabah yang ada pada bank untuk keperluan pembayaran pembiayaan, denda, ganti rugi dan lain sebagainya.

Apabila dalam masa pembiayaan terjadi perselisihan yang timbul akibat akad maka, kedua pihak harus sepakat menyelesaikan perselisihan tersebut melaui musyawarah dan dalam 30 hari hal tersebut telah dilakukan dan perselisihan belum terselesaikan maka para pihak berhak untuk menyelesaikannya melalui Pengadilan Negeri Makassar sesuai dengan ketentuan pasal 18 tentang penyelesaian perselisihan. Itulah sebabnya dalam proses penandatangan akad terdapat domisili hukum yang dipilih apabila terjadi perselisihan pada pasal 19. Hal tersebut sesuai dengan penjelasan "Asdar" Bahwa:

"Kan dalam akad memang sudah dicantumkan apabila terjadi perselisihan antara kedua belah pihak maka proses penyelesainnya itu dulu dilakukan secara musyawarah kalau seumpa masalahnya belum juga bisa diselesaikan maka barulah kepengadilan"

Dalam pembiayaan murabahah bil wakalah dengan dua akad yang digunakan dalam satu produk pembiayaan, maka pasti ada akad yang didahulukan dan ada juga akad yang diakhirkan. Dalam proses penyertaan akad murabahah dan wakalah ini, bank menggunakan akad wakalah terlebih dahulu untuk ditandatangani, setelah barang secara prinsip sudah menjadi milik bank barulah kemudian pihak bank memberikan akad murabahah untuk ditandatangani. Meskipun hal tersebut tidak selalu dijalankan sesuai ketentuan oleh bank-bank syariah lainnya yang menggunakan akad murabahah bil wakalah bahkan tidak menutup kemungkinan ada juga bank BNI Syariah yang tidak mengikuti aturan tersebut. Seperti yang di katakan oleh"Salam M Bustan"

"Sebenarnya, secara teori jika membahas mengenai akad yang harus didahulukan terlebih dahulu jika mengambil pembiayaan yang menggunakan akad murabahah bil wakalah tentunya kita harus mendahulukan akad wakalah karena jika barang secara prinsip belum menjadi 


\section{Nurhikma, Rahman Ambo Masse, Damira}

milik bank sedangkan bank dengan nasabah telah melakukan penandatangan akad murabahah berarti itu sudah terjadi penyimpangan dong, artinya bank sudah menjual barang yang belum ada dan itu menunjukkan sifat gharar yang dilarang dalam islam. Kalau kita disini menjalankan pembiayaan tersebut sesuai dengan aturannya akan tetapi di bank-bank syariah lainnya dan tidak menutup kemungkinan juga Bank BNI Syariah cabang lain menjalankan pembiayaan tersebut tidak sesuai dengan ketentuannya, itu sebenarnya tergantung dari oknum-oknum yang bertanggung jawab didalamnya karena biasanya mereka ingin simplenya saja tanpa memikirkan apakah itu melanggar ketentuan atau tidak, kebanyakan dari mereka tidak mau repot kalau harus bolak balik tandatangani akad, jadi mereka langsung saja kasih akad murabahah sama wakalahnya untu tandatangani secara bersamaan meskipun barang secara pinsip belum jadi miliknya bank."

Dalam hal tersebut peneliti juga melakukan wawancara dengan salahsatu nasabah Bank BNI Syariah Cabang Makassar yang mengambil pembiayaan dengan menggunakan akad murabahah bil wakalah "Irma Haryani" hasil wawancara sebagai berikut:

"Kalau saya ini ambil pembiayaan Griya iB Hasanah untuk bangun kost putri, kebetulan dekat rumah ada lahan kosong daripada nda di manfaatkan jadi saya bangun saja kostkost khusus putri, kalau pas akad itu saya tanda tangani akad wakalah dulu, saya yang beli semua bahan untuk bangun kost-kost ku baru saya tanda tangani lagi akad murabahah, sebenarnya mauka dulu tanda tangani langsung semua saja daripada saya kembali lagi cuma untuk tanda tangan tapi bilang bank tidak boleh, akad murabahah baru bisa di tanda tangani kalau selesai semua mi proses pembelian."

Berdasarkan hasil wawancara tersebut Bank BNI Syariah Cabang Makassar benar-benar sudah menjalankan ketentuan yang berlaku dalam pembiayaan murabahah bil wakalah bahwa akad yang harus didahulukan apabila mengambil pembiayaan menggunakan akad murabahah bil wakalah adalah akad wakalah setelah akad wakalah berakhir atau barang secara prinsip sudah menjadi milik bank sesuai dengan ketentuan Fatwa Dewan Syariah Nasional No: 04/DSN/-MUI/IV/2000 Tentang Murabahah bulir 9 bahwa "Jika bank hendak mewakilkan kepada nasabah untuk membeli barang dari pihak ketiga, akad jual beli murabahah harus dilakukan setelah barang, secara prinsip, menjadi milik bank" serta ketentuan dan syarat yang ada dalam pembiayaan dengan akad murabahah bil wakalah telah diterapkan sesuai dengan ketentuan-ketentuan tersebut.

\section{Kesimpulan}

1. Ketentuan Hybrid Contract dalam pembiayaan murabahah bil wakalah pada Bank BNI Syariah KC Makassar pada dasarnya sama saja dengan ketentuan yang berlaku di BNI Syariah lainnya, hal tersebut dikarenakan dalam ketentuannya telah disesuaikan dengan ketentuan peraturan perundang-undangan termasuk ketentuan Otoritas Jasa Keuangan yang kemudian diatur kedalam beberapa pasal yang diantaranya membahas mengenai ketentuan pembiayaan, tujuan dari pembiayaan, kewenangan bank dalam rangka penyelamatan dan lain sebagainya.

2. Implementasi ketentuan hybrid contract pada pembiayaan murabahah bil wakalah pada Bank BNI Syariah KC Makassar berdasarkan hasi penelitian tersebut belum sepenuhnya sesuai dengan ketentuan-ketentuan yang berlaku. Hal tersebut disebabkan karena perubahan ketentuan pembiayaan murabahah bil wakalah pada bank BNI Syariah Cabang Makassar yang tertuan dalam pasal 2 tentang pembiayaan, dimana pengungkapan harga pokok tidak lagi disebutkan pada saat akad, hal tersebut dikarenakan pemahaman bank BNI Syariah Cabang Makassar bahwa pokok dan margin itu satu kesatuan sehingga harga pokok atau harga beli atas objek murabahah tersebut tidak lagi boleh disebutkan karena hal tersebut dapat mengurangi kesyariahan baik itu pembiayaan dengan akad murabahah murni ataupun dengan akad murabahah bil wakalah sehingga melanggar ketentuan 
murabahah bil wakalah itu sendiri yang tertuan dalam pasal 1 tentang definisi murabahah serta melanggar ketentuan Fatwa Dewan Syariah Nasional No: 04/DSN/-MUI/IV/2000 Tentang Murabahah bulir 6. Sedangkan dalam proses penandatanganan akad murabahah bil wakalah pada BNI Syariah Cabang Makassar telah sesuai dengan ketenuan yang berlaku karena penandatanganan akad tersebut didahului dengan akad wakalah apabila bank belum memiliki objek murabahah yang diperlukan nasabah 
Nurhikma, Rahman Ambo Masse, Damira

\section{Daftar Pustaka}

(2001), M. (2012). Kinerja Keuangan Bank dan Stabilitas Makroekonomi Terhadap Profitabilitas Bank Syariah di Indonesia. Jurnal Keuangan Dan Perbankan, 16(2).

Amir Machmud. (2010). Bank Syariah : Teori, Kebijakan Dan Suatu Studi Empiris Di Indonesia. Erlangga, Jakarta.

Amiruddin, M. M. (2018). IMPOSISI FATWA TERHADAP REGULASI PERBANKAN SYARIAH. Bilancia: Jurnal Studi Ilmu Syariah Dan Hukum, 12(1). https://doi.org/10.24239/blc.v12i1.334

Aprianti, K. (2014). SISTEM OPERASIONAL PERBANKAN SYARIAH. In academia.edu (Vol. 1).

Fahmi, I. (2016). Pengantar Manajemen Keuangan: Teori dan Soal Jawab. In Alfabeta.

Harahap, A. P., \& Saraswati, D. (2020). Bank dan Lembaga Keuangan Lainnya, Jakarta. In Penerbit PT Raga Grafindo Persada. Halaman: 96. (Issue Februari).

Hidayati, N. K., Setyowati, R., \& Mulyani, M. (2021). Hybrid Contract in Sharia Insurance Practices in Indonesia. Jurnal IImiah Ekonomi Islam, 7(03).

Ibrahim, A., \& Salam, A. J. (2021). A comparative analysis of DSN-MUI fatwas regarding murabahah contract and the real context application (A study at Islamic Banking in Aceh). Samarah, 5(1). https://doi.org/10.22373/sjhk.v5i1.8845

Jamin Ginting. (2017). Pengertian dan Sejarah Perbankan di Indonesia. Perbankan Indonesia, 1.

Kariyono. (2019). Implementasi Jual Beli Murabahah Dalam Lembaga Keuangan Syariah. In Tahkim (Vol. 15, Issue 2).

Kholid, M. (2018). PRINSIP-PRINSIP HUKUM EKONOMI SYARIAH DALAM UNDANG-UNDANG PERBANKAN SYARIAH. Asy-Syari'ah, 20(2). https://doi.org/10.15575/as.v20i2.3448

Kurniawan, M. (2021). Bank dan Lembaga Keuangan Syariah (Teori dan Aplikasi) - Google Books. Penerbit Adab.

Kusuma, R. A. (2019). Pengaruh Pembiayaan Mudharabah, Pembiayaan Musyarakah, Pembiayaan Sewa/Ijarah, dan Pembiayaan Murabahah Terhadap Profitabilitas Bank Muamalat Indonesia (Periode 2012-2018). In Analisis Fiqih dan Keuangan.

Masnah, S., \& Hendrawati. (2020). Pengaruh Pembiayaan Mudharabah, Musyarakah, dan Murabahah Terhadap Profitabilitas dengan Non Performing Financing (Npf) Sebagai Variabel Moderasi. Artikel Ilmiah.

Rahman, A. I. el. (2019). EKSEKUSI HAK TANGGUNGAN DALAM PRINSIP EKONOMI SYARI'AH. LAN TABUR: JURNAL EKONOMI SYARI'AH, 1(1).

Rimadhani, M., \& Erza, O. (2017). ANALISIS VARIABEL-VARIABEL YANG MEMPENGARUHI PEMBIAYAAN MURABAHAH PADA BANK SYARIAH MANDIRI PERIODE 2008.01-2011.12. Media Ekonomi, 19(1). https://doi.org/10.25105/me.v19i1.833

Rusby, Z. (2017). Manajemen Perbankan Syariah. In Pusat Kajian Pendidikan Islam UR. 
Segarawasesa, F. S. (2018). Determinan Tingkat Kepatuhan Syariah pada Bank Syariah di Indonesia. In Master of Accountancy.

SN Rokhmana. (2012). ANALISIS PENGARUH RISIKO PEMBIAYAAN TERHADAP PROFITABILITAS (Studi Kasus Pada Bank Muamalat Cabang Semarang). In Walisongo Institutional Repository.

Tripalupi, R. I. (2020). RESTRUKTURISASI PEMBIAYAANMURABAHAH,MUDHARABAHDAN MUSYARAKAH DI BANK SYARIAH DITINJAU DARI PERSPEKTIF HUKUM. ADLIYA: Jurnal Hukum Dan Kemanusiaan, 8(1). https://doi.org/10.15575/adliya.v8i1.8629 